\title{
THE EFFICACY OF USING BIOHUMUS SUBSTRATE IN INTENSIVE CULTIVATION OF VINE SEEDLINGS
}

\author{
Sultonov Komolitdin Sadriddinovich \\ Doctor of Agricultural Sciences, Department of Fruit Growing and Viticulture, \\ Tashkent State Agrarian University, Tashkent, Uzbekistan \\ Eraliyeva Shamshoda Farhod qizi \\ Third Course Bachelor Student, Faculty of Fruit-vegetable Growing and Viticulture, \\ Tashkent State Agrarian University, Tashkent, Uzbekistan
}

\begin{abstract}
Annotation. In this article presented the research results conducted on the study of efficacy of biohumus using norms in propagation of vine seedlings by traditional method - by cuttings. The difference was observed in the development of seedlings when 1-5 kgs of biohumus was applied per pogometers of the area under vine seedlings. And it was determined that this organic fertilizer was given by $4 \mathrm{kgs}$ for well development of vine seedlings.
\end{abstract}

Key words: vine, cutting, biohumus, seedling, root, substrate, shoot, root, variety.

Introduction. The production of vine seedling in the republic from wood cuttings is a general main method. Vine seedlings yield makes $80 \%$ in this method compared to the seedlings sown commonly. By introducing biohumus application to this technological process, the production of seedlings and its profitability can be increased.

Biohumus is an organic substrate and a product of Canadian worms life activity. It contains a lot of macro- and micro-elements essential for plants, it is solvent in water and soil and provides favourable condition for life activity of useful soil microflora. Chemical content of biohumus which was used in experiment as an additional nutrition means consisted of: $\mathrm{pH}-7,6$, sum of soaked base $-33,9 \mathrm{mg}-$ equ/100 g., N-NH $4-5,2 \mathrm{mg} / 100$ g., $\mathrm{N}_{4} \mathrm{NO}_{3}-10,7 \mathrm{mg} / 100$ g., $\mathrm{P}_{2} \mathrm{O}_{5}-272,5 \mathrm{mg} / 100 \mathrm{~g}$., $\mathrm{K}_{2} \mathrm{O}-268,2 \mathrm{mg} / 100 \mathrm{~g}$., $\mathrm{Ca}-10,4 \mathrm{mg} / 100 \mathrm{~g}$. and $\mathrm{Mg}-11,0 \mathrm{mg} / 100 \mathrm{~g}$.

The method of the research. In the experiment were used black Kishmish, Saperavi and pink Taifiy grape varieties and 1-5 kgs of biohumus as an object of the research. Wood cuttings of vine were planted in experimental plot in $70 \times 20 \mathrm{~cm}$ scheme. In each variant 200 pieces of cuttings were planted in four repetitions and was applied biohumus from $1 \mathrm{kgs}$ to $5 \mathrm{kgs}$ amount. The experiment was conducted by using "The methodics on records and phenological observations in the experiments of fruit and berry plants" [2] recommended by Kh.Buriyev and others. Vine seedlings were evaluated during the growth according to the current standard [4].

Research results and their analysis. It is known that the cultivation of welldeveloped vine seedlings requires long-term process, most ecological factors, particularly irrigation and feeding conditions may greatly influence on this process $[3,5]$. Its results refer to the nature of growth and development of seedlings, growth of shoots, leaves and root system $[1,6,7]$. 
Considering this, we paid more attention to phenological observations in our investigations, according to these observations the growth power of plants, the growth of fertilized plants and shoot maturation on them were noted too. The conducted research allowed to determine the privilege of the variants with biohumus compared to the control variant on the growth and development of the plants.

A certain difference was observed in the formation of shoots and leaves of plants fertilized with biohumus depending on the amount of this additional nutrient (1-table).

Table-1

Dynamics of vine seedlings shoots depending on additional feeding with biohumus

\begin{tabular}{|c|c|c|c|c|c|}
\hline \multirow{2}{*}{ Experimental variants } & \multicolumn{5}{|c|}{ Shoot length in observation dates, $\mathrm{cm}$} \\
\hline & $15 . \mathrm{V}$ & $30 . \mathrm{V}$ & 15.VI & $30 . \mathrm{VI}$ & 15.VII \\
\hline \multicolumn{6}{|c|}{ Black Kishmish variety } \\
\hline Control-unfertilized & 19,2 & 27,3 & 38,0 & 56,6 & 67,8 \\
\hline Biohumus, $1 \mathrm{~kg} /$ linear metres (LM) & 20,4 & 28,1 & 40,7 & 58,8 & 69,7 \\
\hline Biohumus, $2 \mathrm{~kg} /(\mathrm{LM})$ & 22,7 & 32,7 & 43,6 & 67,2 & 72,8 \\
\hline Biohumus, 3 kg/ (LM) & 23,5 & 36,4 & 46,3 & 75,2 & 75,3 \\
\hline Biohumus, 4 kg/(LM) & 23,9 & 36,6 & 46,8 & 75,3 & 75,4 \\
\hline Biohumus, $5 \mathrm{~kg} /(\mathrm{LM})$ & 23,9 & 36,8 & 47,1 & 76,1 & 76,1 \\
\hline \multicolumn{6}{|c|}{ Saperavi variety } \\
\hline Control-unfertilized & 15,7 & 22,1 & 33,2 & 48,7 & 57,6 \\
\hline Biohumus, $1 \mathrm{~kg} /(\mathrm{LM})$ & 18,4 & 24,6 & 36,8 & 51,8 & 61,1 \\
\hline Biohumus, $2 \mathrm{~kg} /(\mathrm{LM})$ & 19,8 & 28,1 & 39,1 & 57,3 & 62,8 \\
\hline Biohumus, $3 \mathrm{~kg} /(\mathrm{LM})$ & 20,6 & 31,1 & 41,8 & 61,3 & 69,3 \\
\hline Biohumus, 4 kg/(LM) & 20,7 & 31,4 & 41,9 & 61,6 & 69,4 \\
\hline Biohumus, $5 \mathrm{~kg} /(\mathrm{LM})$ & 20,9 & 31,6 & 42,1 & 61,9 & 69,7 \\
\hline \multicolumn{6}{|c|}{ Pink Taifiy variety } \\
\hline Control-unfertilized & 19,7 & 27,8 & 38,8 & 56,9 & 68,5 \\
\hline Biohumus, $1 \mathrm{~kg} /(\mathrm{LM})$ & 21,2 & 28,6 & 40,9 & 59,1 & 69,9 \\
\hline Biohumus, $2 \mathrm{~kg} /(\mathrm{LM})$ & 22,9 & 32,9 & 43,9 & 67,8 & 73,5 \\
\hline Biohumus, 3 kg/ (LM) & 24,6 & 36,9 & 46,8 & 75,9 & 75,8 \\
\hline Biohumus, 4 kg/(LM) & 24,8 & 37,1 & 47,1 & 76,0 & 76,3 \\
\hline Biohumus, $5 \mathrm{~kg} /(\mathrm{LM})$ & 24,9 & 37,3 & 47,4 & 76,3 & 76,6 \\
\hline
\end{tabular}

Although the growth power of plants fertilized with biohumus was higher during the whole growing period compared to the same indications of plants in control variant, but its most considerable indications were noted in the variant with 3 kgs amount of this additional nutrient.

The study of dynamics of shoots growth depending on additional nutrition biohumus showed that its length had tendency which increased paralelly with the increase in the amount of additional feeding. But the analysis of growth power of shoots allowed to note the highest point and feeding amount when their additional feeding norm was $3 \mathrm{kgs}$, while the next increases showed that there wasn't 
considerable difference in growth power increase. At the last date of observation of shoots length when 1-3 kgs of biohumus was used the increasing amount of shoots length constituted 9; 3,1 and 2,5 cm in black Kishmish variety per $\mathrm{kg}$ of humus, in the variant where 4 and $5 \mathrm{kgs}$ of humus was applied the difference showed 0,1 and 0,8 $\mathrm{cm}$ compared to the variant in which $3 \mathrm{~kg}$ of biohumus was applied.

In the growth power and length of shoots depending on additional feeding with biohumus difference tendency was repeated in Saperavi wine variety and in fresh pink Taifiy variety like it was observed in black Kishmish variety. The length of shoots in the variants fertilized with biohumus was more than in the plants of variants not fertilized with elements. Generally saying, topsoil parts of seedlings cultivated in $3 \mathrm{kgs}$ norm of biohumus nutrition substrate could present the dimensions which correspond to state standard requirements. Biohumus feeding over $3 \mathrm{kgs}$ didn't present considerable changes in shoots growth.

The experiments on biohumus showed that the supply of this additional nutrition caused to considerable difference in the development of assimilation apparatus of seedlings. The results of research showed that in plants fertilized with biohumus the amount of leaves was 1-8 pieces more in black Kishmish variety than in control variant, and this indication in winy Saperavi and fresh pink Taifiy varieties made 1-5 and 1-8 pieces relatively (table- 2 ).

Table-2

Development of assimilation apparatus and maturation level of shoots of vine seedlings.

\begin{tabular}{|c|c|c|c|c|}
\hline \multirow[t]{2}{*}{ Experimental variants } & \multirow{2}{*}{$\begin{array}{l}\text { Leaves q-ty, } \\
\text { pcs/plants }\end{array}$} & \multirow{2}{*}{$\begin{array}{l}\text { Total square of leaf } \\
\text { surface of one plant, } \mathrm{cm}^{2}\end{array}$} & \multicolumn{2}{|c|}{$\begin{array}{c}\text { Maturation level of } \\
\text { shoot }\end{array}$} \\
\hline & & & $\mathrm{cm}$ & $\%$ \\
\hline \multicolumn{5}{|c|}{ Black Kishmish variety } \\
\hline Control-unfertilized & 8 & 512 & 60,2 & 91,4 \\
\hline Biohumus, $1 \mathrm{~kg} /(\mathrm{LM})$ & 9 & 671 & 63,5 & 93,2 \\
\hline Biohumus, $2 \mathrm{~kg} /(\mathrm{LM})$ & 12 & 728 & 70,1 & 94,6 \\
\hline Biohumus, $3 \mathrm{~kg} /(\mathrm{LM})$ & 15 & 878 & 73,5 & 97,2 \\
\hline Biohumus, $4 \mathrm{~kg} /(\mathrm{LM})$ & 16 & 880 & 73,9 & 96,3 \\
\hline Biohumus, $5 \mathrm{~kg} /(\mathrm{LM})$ & 16 & 888 & 74,5 & 96,3 \\
\hline \multicolumn{5}{|c|}{ Saperavi variety } \\
\hline Control-unfertilized & 7 & 478 & 51,3 & 90,8 \\
\hline Biohumus, 1 kg/(LM) & 8 & 599 & 52,5 & 92,1 \\
\hline Biohumus, $2 \mathrm{~kg} /(\mathrm{LM})$ & 11 & 679 & 59,2 & 94,3 \\
\hline Biohumus, $3 \mathrm{~kg} /(\mathrm{LM})$ & 12 & 751 & 61,4 & 96,4 \\
\hline Biohumus, $4 \mathrm{~kg} /(\mathrm{LM})$ & 12 & 768 & 61,9 & 96,4 \\
\hline Biohumus, $5 \mathrm{~kg} /(\mathrm{LM})$ & 13 & 791 & 62,5 & 95,9 \\
\hline \multicolumn{5}{|c|}{ Pink Taifiy variety } \\
\hline Control-unfertilized & 9 & 549 & 64,3 & 91,9 \\
\hline Biohumus, $1 \mathrm{~kg} /(\mathrm{LM})$ & 10 & 632 & 65,5 & 92,4 \\
\hline Biohumus, $2 \mathrm{~kg} /(\mathrm{LM})$ & 13 & 792 & 69,3 & 94,5 \\
\hline
\end{tabular}




\begin{tabular}{|l|c|c|c|c|}
\hline Biohumus, $3 \mathrm{~kg} /(\mathrm{LM})$ & 16 & 892 & 78,1 & 97,8 \\
\hline Biohumus, $4 \mathrm{~kg} /(\mathrm{LM})$ & 16 & 898 & 78,9 & 97,4 \\
\hline Biohumus, $5 \mathrm{~kg} /(\mathrm{LM})$ & 17 & 901 & 79,5 & 97,9 \\
\hline
\end{tabular}

The difference was observed in total area of leaf depending on nutrition norms. In unfertilized control variant total square of leaf surface was $512 \mathrm{~cm}^{2}$ in black Kishmish variety, in winy Saperavi variety 478 and in fresh pink Taifiy $549 \mathrm{~cm}^{2}$. Depending on biohumus application norm the increase in total square of leaf surface constituted 671-888 in black Kishmish variety, in winy Saperavi variety 599-791 and in pink Taifiy it was $632-901 \mathrm{~cm}^{2}$.

It should be emphasized that the increase in total square of leaf surface was strong when biohumus was applied in $3 \mathrm{kgs}$ norm, but further increases of biohumus norm didn't show considerable dimensions. It means that there is no need to use biohumus over $3 \mathrm{kgs}$ norm.

It is known that vine vegetation period lasts long. Therefore, some parts of shoots even aren't mature enough during their covering in autumn. Finally, in order to get qualitative seedling the shoots are to be mature enough.

The results of abovementioned table define high maturation indication of shoots in seedlings which were processed with biohumus. Particularly, in control variant the total length of shoots was 67,$8 ; 57,6$ and $68,5 \mathrm{~cm}$ relatively according to varieties and mature parts out of these constituted 60,$2 ; 51,3$ and $64,3 \mathrm{~cm}$, while in the variant with biohumus the mean length of mature parts of shoots was found to be the best one $(3 \mathrm{kgs} / \mathrm{m})$ in black Kishmish variety - 73,5, in Saperavi variety - 61,4 and in pink Taifiy variety it was $78,1 \mathrm{~cm}$. Obviously, according to shoots maturation level the experimental variants processed with $3 \mathrm{kgs}$ biohumus was considerably higher compared to control variant and showed 96,4-98,2\%.

Vine seedlings of high quality should have well-developed root system in lower parts, because the top roots of seedlings may die in summer drought and may be damaged by winter frost. The task of cultivating qualitative vine seedlings which can correspond to standard requirements, has been prior in our republic, and today this task is regarded as an essential problem with shortage of scare vine varieties seedlings for cultivation.

The root system of vine seedlings developed well in bottom part of plant, in the variants with biohumus the first order roots quantity which developed in plants was 10,3-12,9 pieces in black Kishmish variety, in Saperavi 9,9-11,5 and in pink Taifiy $11,1-12,5$ pieces, their total length was between 45,6-68,1; 45,5-62,2 and 48,9-68,3 $\mathrm{cm}$ relatively. The proper regeneration of roots was observed in plants processed with biohumus by $3 \mathrm{kgs}$ of biohumus per meter length. Although the root regeneration was higher than in control variant when biohumus amount was increased to 4-5 kgs, but its less difference in comparison with the variants with $3 \mathrm{kgs}$ biohumus showed that there was no need to increase additional nutrition in such level (table-3).

The influence of biohumus application on the development of vine cuttings 


\begin{tabular}{|c|c|c|c|c|c|c|c|}
\hline \multirow[b]{2}{*}{ Experimental variants } & \multicolumn{2}{|c|}{ Bottom part } & \multicolumn{2}{|c|}{ Top part } & \multicolumn{2}{|c|}{ Total } & \multirow{2}{*}{$\begin{array}{c}\text { Growing } \\
\text { capability } \\
\text { of } \\
\text { seedlings } \\
\text { in vinery, } \\
\%\end{array}$} \\
\hline & $\begin{array}{l}\text { First order } \\
\text { roots, } \\
\text { pcs/plant. }\end{array}$ & $\begin{array}{l}\text { Length of } \\
\text { total roots, } \\
\mathrm{cm}\end{array}$ & $\begin{array}{l}\text { First order } \\
\text { roots, } \\
\text { pcs/plant. }\end{array}$ & $\begin{array}{l}\text { Length of } \\
\text { total roots, } \\
\mathrm{cm}\end{array}$ & $\begin{array}{l}\text { First order } \\
\text { roots, } \\
\text { pcs/plant. }\end{array}$ & $\begin{array}{c}\text { Length of } \\
\text { total roots, } \\
\mathrm{cm}\end{array}$ & \\
\hline \multicolumn{8}{|c|}{ Black Kishmish variety } \\
\hline $\begin{array}{l}\text { Control- } \\
\text { unfertilized }\end{array}$ & 9,9 & 43,5 & 5,5 & 9,7 & 15,4 & 53,1 & 83,1 \\
\hline $\begin{array}{l}\text { Biohumus, } 1 \\
\mathrm{~kg} /(\mathrm{LM})\end{array}$ & 10,3 & 45,6 & 5,8 & 10,8 & 16,1 & 56,4 & 84 \\
\hline $\begin{array}{l}\text { Biohumus, } 2 \\
\mathrm{~kg} /(\mathrm{LM})\end{array}$ & 11,1 & 54,8 & 5,9 & 15,9 & 17,0 & 71,8 & 88,6 \\
\hline $\begin{array}{l}\text { Biohumus, } 3 \\
\mathrm{~kg} /(\mathrm{LM})\end{array}$ & 12,5 & 67,4 & 6,0 & 20,0 & 18,4 & 87,4 & 94,8 \\
\hline $\begin{array}{l}\text { Biohumus, } 4 \\
\mathrm{~kg} /(\mathrm{LM})\end{array}$ & 12,8 & 67,9 & 6,1 & 20,0 & 18,9 & 87,9 & 95,0 \\
\hline $\begin{array}{l}\text { Biohumus, } 5 \\
\mathrm{~kg} /(\mathrm{LM})\end{array}$ & 12,9 & 68,1 & 6,1 & 20,8 & 19,0 & 88,9 & 95,1 \\
\hline \multicolumn{8}{|c|}{ Saperavi variety } \\
\hline $\begin{array}{l}\text { Control- } \\
\text { unfertilized }\end{array}$ & 9,1 & 40,6 & 4,4 & 9,2 & 13,5 & 49,8 & 82,5 \\
\hline $\begin{array}{l}\text { Biohumus, } 1 \\
\mathrm{~kg} /(\mathrm{LM})\end{array}$ & 9,9 & 45,5 & 4,6 & 11,4 & 14,5 & 56,9 & 85,1 \\
\hline $\begin{array}{l}\text { Biohumus, } 2 \\
\mathrm{~kg} /(\mathrm{LM})\end{array}$ & 10,4 & 54,3 & 4,9 & 15,2 & 15,3 & 69,5 & 90.7 \\
\hline $\begin{array}{l}\text { Biohumus, } 3 \\
\mathrm{~kg} /(\mathrm{LM})\end{array}$ & 11,2 & 61,3 & 5,1 & 19,3 & 16,3 & 80,6 & 93,6 \\
\hline $\begin{array}{l}\text { Biohumus, } 4 \\
\text { kg/(LM) }\end{array}$ & 11,3 & 61,8 & 5,1 & 19,4 & 16,4 & 81,2 & 94,0 \\
\hline $\begin{array}{l}\text { Biohumus, } 5 \\
\mathrm{~kg} /(\mathrm{LM})\end{array}$ & 11,5 & 62,2 & 5,2 & 19,8 & 16,7 & 82,0 & 94,2 \\
\hline \multicolumn{8}{|c|}{ Pink Taifiy variety } \\
\hline $\begin{array}{l}\text { Control- } \\
\text { unfertilized }\end{array}$ & 10,3 & 43,2 & 5,4 & 9,9 & 15,7 & 53,1 & 83,3 \\
\hline $\begin{array}{l}\text { Biohumus, } 1 \\
\mathrm{~kg} /(\mathrm{LM})\end{array}$ & 11,1 & 48,9 & 5,7 & 13,4 & 16,8 & 62,3 & 84,9 \\
\hline $\begin{array}{l}\text { Biohumus, } 2 \\
\mathrm{~kg} /(\mathrm{LM})\end{array}$ & 11,6 & 55,6 & 5,8 & 18,1 & 17,4 & 73,7 & 91,2 \\
\hline $\begin{array}{l}\text { Biohumus, } 3 \\
\mathrm{~kg} /(\mathrm{LM})\end{array}$ & 12,2 & 67,2 & 5,8 & 20,4 & 18,0 & 87,3 & 93,8 \\
\hline $\begin{array}{l}\text { Biohumus, } 4 \\
\mathrm{~kg} /(\mathrm{LM})\end{array}$ & 12,3 & 67,8 & 5,9 & 20,8 & 18,2 & 88.6 & 94,0 \\
\hline $\begin{array}{l}\text { Biohumus, } 5 \\
\mathrm{~kg} /(\mathrm{LM})\end{array}$ & 12,5 & 68,3 & 5,9 & 21,1 & 18,4 & 89.4 & 94,8 \\
\hline $\mathrm{EKF}_{05}$ & 3,8 & 27,7 & 1,7 & 11,9 & 5,0 & 39,6 & 12,6 \\
\hline
\end{tabular}

Favourable nutrition order in the application of biohumus provided rapid development of topsoil part and root system of vine seedlings, and allowed to increase the capacity of production of qualitative seedlings. The highest production of 
standard seedlings was observed in biohumus applied variants in black Kishmish variety 60142-67928 pieces, in Saperavi variety it was between 60785-67213 and in pink Taifiy variety 60642-67713 pieces/ha (picture). The picture informs that if we plant wood cuttings of vine by applying biohumus it may influence positively on total yield of seedlings, and increases the amount of standard seedlings production.

It should be emphasized that the increase in seedling production amount depending on biohumus amount showed inconsiderable dimensions after over $3 \mathrm{kgs} /$ $\mathrm{m}$, and therefore it is expedient to use biohumus in $3 \mathrm{kgs} / \mathrm{m}$ norm in seedling cultivation from wood cuttings.

Conclusion. As a nutrition substrate the application of biohumus in $3 \mathrm{kgs}$ norm in per meter length of vinery interrows is regarded effective agrotechnical measure, three bud - wood cuttings which were planted to be rooted, may form 15 pieces of leaves with total square of assimilation surface $878 \mathrm{~cm} 2$ and total length of shoots $75,6 \mathrm{~cm}$ by the end of vegetation.

When vine seedlings are grown from wood cuttings the application of biohumus in $3 \mathrm{kgs}$ per meter length allowed to obtain the seedlings with total length of 117,5 $\mathrm{cm}$ and 18 pieces of formed roots by the end of vegetation. At the same time in control variant plants this indication was found to be 1,5-2,2 times less.

\section{Used references:}

1. Avakyan S.T. The influence of fertilizers on the development of root-producing vine seedlings // Viticulture and winemaking in USSR.-Moscow, 1985.-№2.p.42-43.

2. Buriyev Kh.Ch., Yenileyev N.Sh. et el. The methodics on records and phenological observations for conducting experiments on fruit and berry plants. Tashkent, 2014.p - 64 .

3. Gadjiyev G.M. The influence of fertilizers on the quality of grape. - Moscow: Kolos, 1969. - p. 107-109.

4. GOST 1191-2009 (UzSS 1191-2009). Vine seedlings and cuttings. General technical terms. - Tashkent, 2009.p - 12.

5. Deryugin I.P., Kulyukin A.M. Nutrition and fertilizers for vegetable and fruit culture. - Moscow: MSKHA, 1998.- p. 30-31.

6. Semenyuk G.M. Diagnosis of mineral nutrition of fruit culture. Methodological instruction. - Kishinyev: Shtinsa, 1983. - p. 91-98.

7. Tserling V.V. Diagnosis of nutrition of agricultural culture. - reference book, Moscow, Agropromizdat, 1990.- p. 12-64. 